\title{
The Early Years of the Iowa Democratic Revival, 1950-1956
}

\author{
Thomas G. RYAN
}

\begin{abstract}
A
MONG THE MAJOR DEVELOPMENTS in American politics during the third quarter of the twentieth century was a decrease in traditional sectional voting behavior and an accompanying increase in the number of competitive states. Although the South is the most obvious example of these developments, with a sharply increased Republican vote since the early 1950s, counter trends have emerged in the western Middle West and in northern New England, two areas where the Democratic vote has increased markedly in the last twenty-five years. ${ }^{1}$

Since the first Eisenhower election in 1952, historians, political scientists and journalists have chronicled and analyzed the
\end{abstract}

An earlier version of this article was presented to the 1978 meeting of the Iowa College Teachers of History. The author would like to thank Charles E. Quirk and Robert L. Ross, both of Northern Iowa, for their comments and suggestions on the earlier draft. He would also like to thank the University of Northern Iowa for the financial support which facilitated the research and the writing, and UNI's Academic Computing Center for its technical assistance in analyzing quantitative data.

${ }^{1}$ An indication of the increased Republican vote in the South, and the reverse phenomenon in a number of northern states, is readily availlable in Richard M. Scammon, ed., America at the Polls: A Handbook of American Presidential Election Statistics, 1920-1964 (Pittsburgh: University of Pittsburgh Press, 1965), and Guide to U.S. Elections (Washington: Congressional Quarterly, 1976). 
changes in southern politics in a massive. body of literature. ${ }^{2}$ Marked Democratic gains in the western Middle West and in northern New England during these same years, however, have attracted far less attention from both journalistic and academic observers of American politics. Iowa is one midwestern state whose Democratic party has recorded some of the most striking gains registered by a former minority party since 1950 .

Analysis of aggregate voting and demographic data, as well as of newspaper accounts of Iowa politics, indicates that Republican gubernatorial factionalism contributed more than any other factor to the increased Democratic gubernatorial vote of 1952, 1954, and 1956, the first and most important development in the early years of the Iowa Democratic revival. Republican gubernatorial factionalism explains 1950s Democratic gubernatorial gains better than do either urbanization-industrialization or Democratic party revitalization, the two factors most frequently cited in earlier attempts to account for the increased Democratic share of the Iowa vote. Although urbanization and industrialization preceded and accompanied the increasing Democratic vote for governor, analysis of demographic and of voting data reveals that the party's share of the vote increased no more rapidly in urban than in rural areas. After 1952, the Democratic percentage of the Iowa vote for both governor and president increased most sharply in rural areas buffeted by the falling farm prices which characterized the years of the first Eisenhower administration. The role of Republican gubernatorial factionalism in contributing to the increased Democratic vote of the early and mid-1950s is also apparent in the much larger gains posted by Democratic candidates for governor than by the party's nominees for other offices. Republican gubernatorial weakness, rather than across-the-board Democratic strength, explains the shift in the 1950 to 1956 gubernatorial voting behavior of Iowans.

\footnotetext{
${ }^{2}$ For an introduction to the burgeoning literature on political change in the South see, among others, Jack Bass and Walter DeVries, The Transformation of Southern Politics: Social Change and Political Consequences Since 1945 (New York: Basic Books, 1976); Monroe Lee Billington, The Political South in the Twentieth Century (New York: Scribners, 1975); and William C. Havard, ed., The Changing Politics of the South (Baton Rouge: Louisiana State, 1972).
} 
In viewing the Iowa political landscape of the last forty years, 1956 stands out as the pivotal year. In 1956, Iowans elected a Democratic governor for the first time in twenty years. They also elected a Democrat to the United States House of Representatives for the first time since 1940. Unlike the Democratic gains of 1932, which were massive, depression-based, and temporary, the 1956 achievements were limited, do not appear to have been related to such national phenomena as the business cycle, or to international developments, and have continued to grow, albeit irregularly, in the quarter century following that election.

As Table 1 indicates, the election of a Democratic governor in 1956 resulted neither from a sharp increase in the Democratic percentage of the gubernatorial vote between 1954 and 1956, nor from a steady increase in the Democratic share of the vote over a period of several elections. In electoral terms, two factors produced a 1956 Democratic gubernatorial triumph. One was a modest increase (2.9 percentage points) in the Democratic percentage of gubernatorial vote between 1954 and 1956; the other was a sharp increase ( 7.3 percentage points) in the Democratic gubernatorial vote four years earlier. ${ }^{3}$

Thus the origins of the state's Democratic revival are in the 1952 election, the first bid for the state's highest office by Herschel Loveless, the successful Democratic gubernatorial candidate in 1956. In the first Loveless election, despite the landslide victory registered by the remainder of the Republican ticket in Iowa, the Republican gubernatorial candidate, William S. Beardsley, won re-election with less than 52.0 percent of the vote, the first Republican gubernatorial candidate in sixteen years to fall below that figure. Beardsley not not only ran 7.2 percentage points behind his own 1950 share of the vote, but

${ }^{3}$ Unless indicated otherwise, changes in a candidate's (or a party's) vote from election to election, or the variation between votes received by a party's candidates for different offices in the same election, refer to increases or decreases in the candidate's (party's) share of the vote, rather than to changes in the number of votes received. The 2.9 percentage point increase in the Democratic gubernatorial vote between 1954 and 1956 indicates that the party's share of the vote for that office increased from 48.3 percent in 1954 to 51.2 percent in 1956 .

Whenever the quantitative data cited in the text are taken from the tables included in the paper, no further citations to the sources of those data will be given. 
The Annals of Iowa

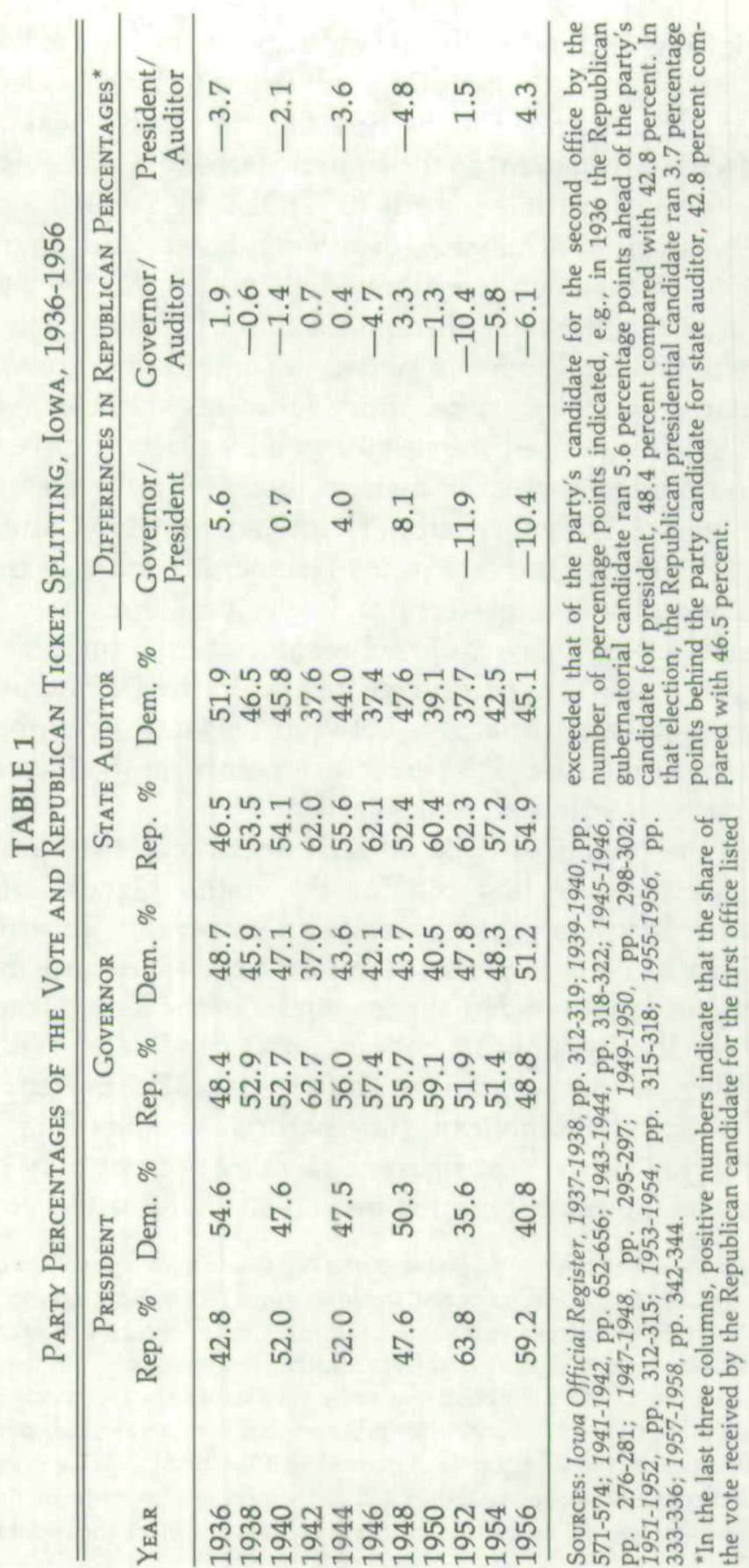


trailed the 1952 Republican presidential candidate, Dwight D. Eisenhower, by 11.9 percentage points.

On the Republican side the 1952 election was notable on several counts. One was the decrease of 7.2 percentage points in the party's share of the gubernatorial vote between 1950 and 1952. This was the largest decline in the Republican share of the vote for that office in consecutive elections since the Depression losses of 1930 to $1932 .{ }^{4}$ The earlier decrease, however, was part of an across-the-board decline in the party's vote, as large numbers of voters vented their anger at the Great Depression on Republican candidates at all levels. The 1950 to 1952 drecrease in the Republican gubernatorial vote, unlike the decrease twenty years earlier, came in an election when other Republican candidates ran ahead of the vote in 1948 and in 1950.

A second noteworthy characteristic of the 1952 election in Iowa was the sharp contrast between the Republican presidential and gubernatorial votes. While Beardsley won 7.2 percentage points less in the 1952 vote than he had in 1950, Eisenhower's percentage of the presidential vote was 16.2 percentage points ahead of Thomas E. Dewey's in 1948. Eisenhower was the first Republican presidential candidate since Herbert Hoover in 1928 to capture more than 52.0 percent of the Iowa vote. His 63.8 percent exceeded the percentage of all other Republican presidential candidates in Iowa since Warren G. Harding won 70.9 percent in $1920 .{ }^{5}$

The divergent paths of the Republican presidential and gubernatorial votes in 1952 resulted from a third feature of the election, a marked increase in split-ticket voting. The minimum figure was 11.9 percent, the difference between the Eisenhower and the Beardsley percentages of the vote. This was more than double the average amount of ticket splitting in the six presidential elections preceding $1952 .^{6}$

A substantial increase in the number of votes cast, and in the percentage of eligible voters who went to the polls, also dis-

${ }^{4}$ Iowa Official Register, 1931-1932, pp. 436-437; 1933-1934, pp. 248-249; 1935-1936, pp. 314-315.

${ }^{5}$ Official Register, 1921-1922, pp. 452-454; 1925-1926, pp. 536-537; 1929-1930, pp. 422-423; 1933-1934, pp. 248-249.

'Official Register, 1929-1930, pp. 422-423; 1933-1934, pp. 248-249. 
tinguished the 1952 presidential election. As Table 2 indicates, the number of Iowans voting for president jumped more than 230,000 between 1948 and 1952, an increase of 22.2 percent. The state's voter turnout rate increased from 62.4 percent in 1948 to 75.8 percent in $1952 .^{7}$

Because the increase in the total vote and the increase in the Republican percentage of the presidential vote were both large and pervasive in 1952, occurring throughout the nation, previous accounts give these developments considerable attention. Less obvious, because most observers of American politics focus on presidential contests, was a marked increase in the total vote, and in voter turnout, in the off-year election immediately preceding the first Eisenhower-Stevenson contest. As Table 2 suggests, between 1946 and 1950 the total gubernatorial vote in Iowa increased 39.7 percent, well over half again as much as the 22.2 percent increase in the presidential vote between 1948 and 1952 . This development was not unique to Iowa. Between 1946 and 1950, the number of persons voting for governor increased in thirty-three of the thirty-four states holding gubernatorial elections both years, with a mean increase of 28.0 percent in the thirty-four states. Thus the increase in voter turnout associated with the Eisenhower years began two years before the general's first bid for the presidency. ${ }^{8}$

Although the party's percentage of the gubernatorial vote decreased more than seven percentage points from 1950 to 1952, Iowa Republicans retained the governorship, as William Beardsley won a third term. Two years later, when each party nominated a new candidate for governor, the Republicans again won a close election, as Table 1 indicates, with neither party's share of the vote changing more than one-half of one percentage point. Despite the 1954 Republican victory and the negligible change in each party's share of the vote, the Democratic percentage increased slightly. Clyde E. Herring, the son of a former Democratic governor and United States senator, won 48.3

${ }^{7}$ U.S. Bureau of the Census, Historical Statistics of the United States: Colonial Times to 1970, Bicentennial Edition, Part 1 (Washington, 1975), p. 1071.

${ }^{8}$ Richard M. Scammon, ed., America Votes: A Handbook of Contemporary American Election Statistics, 1 (New York: Macmillan, 1956), passim. 
Iowa Democratic Revival

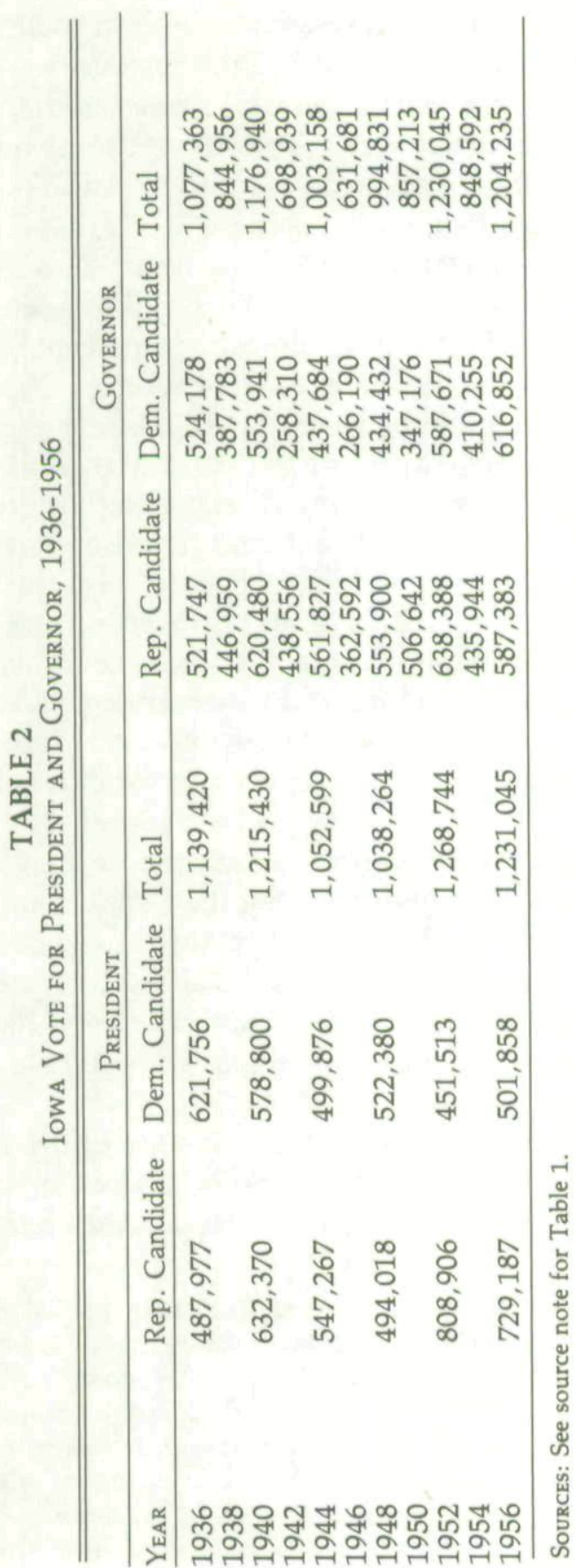


percent of the vote, the largest percentage of any Democratic gubernatorial candidate since 1936, the last year that party captured the statehouse. Herring's total suggested that the 1952 Democratic gubernatorial vote was not fortuitous, and that a high degree of competition had returned to Iowa politics, at least in contests for the governorship.

The narrow Republican gubernatorial victory in 1954, like that in 1952, revealed widespread ticket splitting as the new governor, Leo A. Hoegh, ran almost six percentage points behind the Republican candidate for state auditor. This was the second largest differential between the Republican percentages of the vote for these two offices since 1920, and was almost four times the mean differential in the fifteen elections from 1922 through $1950 .{ }^{9}$ Considerable ticket splitting also characterized the 1954 contest for the United States Senate, with the Republican challenger, Congressman Thomas E. Martin, running well behind the normal Republican vote, i.e., the vote for state auditor. Although Martin defeated the incumbent, Democratic Senator Guy M. Gillette, his share of the vote was five percentage points less than that of the Republican candidate for state auditor. ${ }^{10}$

In addition to the small Republican margin in the governor's race and the large differential between the Republican vote for governor and that for auditor, a third feature of recent elections also characterized the 1954 contest. As Table 2 indicates, voter turnout continued at about the same relatively high level recorded in 1950, and well above the 1942 and 1946 turnout figures.

If any doubts existed regarding the reliability of the 1952 and 1954 gubernatorial election results as indicators of on-going political developments in Iowa, the 1956 contest erased them.

${ }^{9}$ Official Register, 1921-1922, pp. 461-462; 1923-1924, pp. 497-498; $1925-$ 1926 , pp. $542-543 ; 1927-1928$, pp. $460-461 ; 1929-1930$, pp. $426-427 ; 1931-$ 1932, pp. 440-441; 1933-1934, pp. 250-251; 1935-1936, pp. 316-317.

${ }^{10}$ Official Register, 1955-1956, pp. 334-336. Martin's relatively poor showing, like Hoegh's, resulted from a factor other than a basic realignment of the lowa electorate. His opponent was a popular incumbent who had run far ahead of the rest of the ticket in 1948, when he and President Harry S. Truman were the only Democrats to win statewide contests in Iowa. 
Although Eisenhower and most other Republican candidates carried the state handily, Iowa Democrats won the governorship for the first time in twenty years. Herschel Loveless, who had run well in his first bid in 1952, not only won election, but also captured a larger percentage of the vote than all but two previous Democratic gubernatorial candidates since $1885 .{ }^{11}$ Only in the landslide Depression years of 1932 and 1934 did Iowa Democrats win the governorship with a larger percentage of the vote than Loveless captured in 1956.

Iowa election results since 1956 attest to the importance of the Loveless-Hoegh contest as the beginning of a new era in Iowa political life. Since 1956, the former minority party has attained a status of rough equality with the Iowa Republican party in such areas as electoral success in both statewide and local contests, and in the number of registered voters who identify with each of the two major parties. Unlike earlier Democratic gubernatorial victories such as those of Horace Boies in 1889 and 1891, Herschel Loveless' triumphs in 1956 and 1958 contributed significantly to a subsequent realignment of the Iowa electorate. ${ }^{12}$

Although most journalists and academicians have largely ignored recent Democratic gains in the western Middle West and northern New England, a few observers have described and attempted to explain these developments. An Iowa City native described and analyzed the state's Democratic revival in his 1977 Harvard senior honors thesis, a journal article, and a book. ${ }^{13}$ Iowa journalists also usually attempt to explain the election results they describe.

${ }^{11}$ Official Register, 1886 , pp. $90-91 ; 1888$, p. $139 ; 1890$, p. $190 ; 1892$, p. 233 ; 1894 , p. $186 ; 1896$, p. $222 ; 1898$, p. $227 ; 1900$, p. $314 ; 1902$, p. $368 ; 1904$, p. $347 ; 1907-1908$, p. $490 ; 1909-1910$, p. $485 ; 1911-1912$, p. $448 ; 1913-1914$, p. $483 ; 1915-1916$, p. $506 ; 1917-1918$, p. $485 ; 1919-1920$, p. 364.

${ }^{12}$ Chiefly because the Republican party was badly divided on the question of temperance legislation, Boies, a former Republican, captured the governorship in 1889 and again in 1891 . These were the first Democratic gubernatorial victories since Stephen Hempstead's in 1849 and 1851, and the last until Clyde Herring's in 1932 and 1934. Official Register, 1977-1978, pp. 292-294.

${ }^{13}$ James C. Larew, "A Party Reborn: The Democrats in Iowa, 1950-1974", 
Previous interpretations of the early stages of the Iowa Democratic renaissance are chiefly of two types - those which emphasize long-term developments and those which focus on more immediate events. Among the long-term developments which are alleged to have contributed to the Democratic revival in Iowa are the urbanization and the industrialization of the state. According to this interpretation, as increasing proportions of Iowans moved to urban areas and accepted non-agricultural employment after World War II, substantial numbers of them modified their political values and priorities regarding such questions as labor unions, unemployment insurance, taxation, legislative apportionment, social services, and such aspects of personal conduct as the use of alcoholic beverages. According to those who emphasize these basic changes in the structure of society and in Iowans' perceptions of a desirable social and political order, the Democratic party responded to changing conditions and to new demands by the voters more readily than the Republican party; thereby it gained the support of increasing numbers of Iowa voters, particularly those in urban areas. Although many of these developments culminated during the governorship of Harold Hughes, in the 1960s, writers who emphasize changes in the state's economy and demography locate many of these developments in the seventeen years preceding Hughes's first election as governor. ${ }^{14}$

A second interpretation emphasizes the reorganization, the revitalization and the modernization of the Democratic party in Iowa. According to this view, the Democratic party would achieve equality with its chief rival only if it shed its traditional image, both as a loser and as a dispenser of patronage, and become a highly organized, issue-oriented, and urban-based political mechanism. Proponents of this view regard the dis-

(senior honors thesis, Harvard University, 1977); “'A Party Reborn: Harold Hughes and the Iowa Democrats," Palimpsest 59 (October 1978): 148-161; A Party Reborn: The Democrats of Iowa, 1950-1974 (Iowa City: Iowa State Historical Department, 1980). All subsequent citations to Larew's work will be to the 1980 volume.

${ }^{14}$ Larew, A Party Reborn, pp. 8-9, 21-34, 46-57, 63-68, 75, 85-87, 136; Elizabeth Drew, "A Reporter at Large: John C. Culver - II," New Yorker, 54 (18 September 1978): 46. 
missal of Jake More as state party chairman, and the rise to prominence of such men as Wade Clarke, Neal Smith, Lex Hawkins, and Robert L. Johnston as critical to the transformation of Iowa politics from Republican dominance to two-party balance and competition. Those who emphasize the role of organization in party affairs also note the later efforts of such men as Dick Clark and John Culver in organizing the Second Congressional District, and later the entire state, in Culver's and Clark's successful congressional and senatorial races of 1964 through $1974 . .^{15}$

The urbanization-industrialization interpretation of Democratic gains in Iowa explains little, if any, of the early advances in the state's Democratic revival. Although the increase in the party's percentage of the gubernatorial vote between 1950 and 1952 correlated positively with the percentage of the male labor force in manufacturing, as indicated in Table 3, the 1954 to 1956 Democratic increase correlated negatively with manufacturing employment. For the entire period, 1950 to 1956, there was virtually no relationship between the Democratic increase and the proportion of males employed in manufacturing.

When 1950 to 1956 Iowa voting behavior is compared with the degree of urbanization, rather than with the relative size of the manufacturing labor force, the results are similar. Although the most urban Iowa counties recorded above-average increases in their Democratic percentage of the gubernatorial vote between 1950 and 1952, they registered small Democratic gubernatorial increases than less urban counties between 1954 and 1956, and between 1950 and $1956 .{ }^{16}$

Similar conclusions follow from a comparison of the Democratic gubernatorial gains with the relative size of the agricultural labor force. Between 1950 and 1952, the most agrarian counties recorded smaller Democratic increases than other counties. Four years later, however, the same counties registered the largest Democratic increases. In the six-year period covered by the four gubernatorial elections of 1950 through 1956, the

${ }^{15}$ Larew, A Party Reborn; Drew, "Reporter," p. 46.

${ }^{16}$ For an indication of the measurement of urbanism, see George B. Mather, Effects of the Use of Voting Machines on Total Vote Cast: Iowa-1920-1960 (Iowa City: Institute of Public Affairs, 1964), pp. 12-13. 
The Annals of Iowa

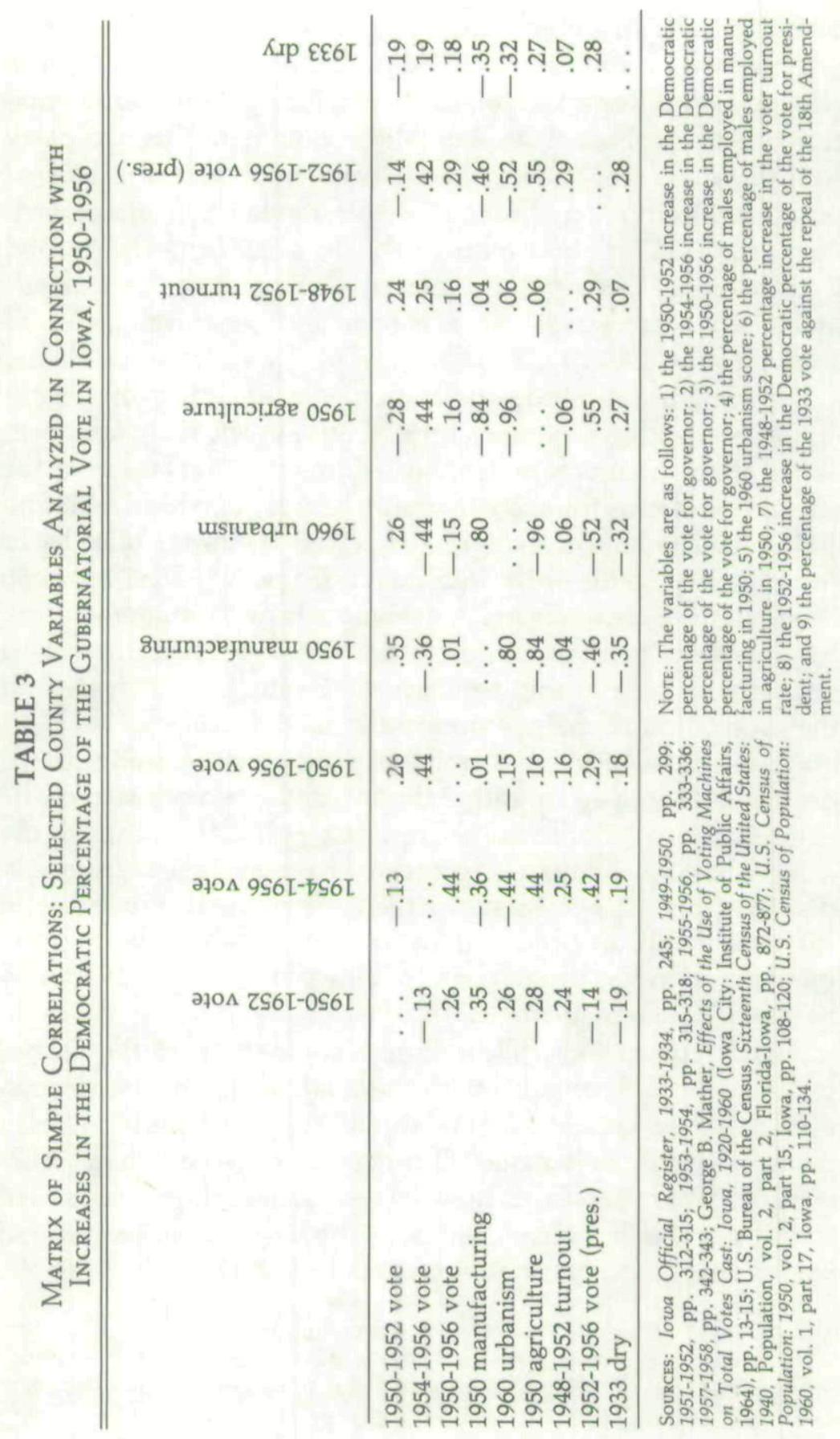


size of the Democratic increase correlated slightly with the size of the agricultural labor force.

In the early years of the Iowa Democratic revival, urbanindustrial counties recorded slightly smaller, not larger, Democratic percentage gains than more rural counties. Because of their larger populations, urban counties may have contributed more votes to the increased Democratic tally than rural counties, but there is no evidence that the Democratic percentage of the vote increased more rapidly in urban counties in the first seven years of the 1950 s.

Interpretations of recent Iowa Democratic gains which emphasize the role of a reorganized and revitalized Democratic party organization concentrate on the period after 1958, the year in which Jake More's critics succeeded in ousting him from the chairmanship, with particular emphasis on the six years following the election of 1960, when Lex Hawkins headed the Iowa Democratic party. Because of the time element, it is difficult to assess the impact of party organization work on the Iowa Democratic vote during the period covered by the present study. Despite this difficulty, however, the prominent role of men like Lex Hawkins, Wade Clarke, Neal Smith, and Robert Johnston in the Polk County Democratic party, in the decade before they captured control of the state organization, provides an opportunity to assess the impact of their organizational work on voting behavior during the early years of the Iowa Democratic revival. This can be done by comparing Democratic achievements in Polk County with those in the rest of the state during the years when Hawkins and others perfected their methods in the state's largest county. If improved organizational techniques contributed as much to the Iowa Democratic revival as the admirers of the new methods contend, the accomplishments of the Polk County Democratic organization should have surpassed those of other county units during the decade preceding More's defeat.

A comparison of developments in Polk County with those in the rest of the state during these years offers little, if any, support for interpretations which attribute much of the Democratic renaissance to a revitalized party organization. Between 1950 and 1956, the Democratic percentage of the gubernatorial vote 
in Polk County increased somewhat less than the statewide figure, 9.3 percentage points compared with 10.7 percentage points.

A comparison of the increase in voter turnout in Polk County and the rest of the state, in the late 1940s and early 1950s, could be interpreted as offering some support for those who emphasize the voter-registration activities and the election-day efforts to get out the vote of the Polk County Democratic organization, as an important source of the increase in the Democratic share of the vote. Voter turnout in Iowa's largest county increased more than in the rest of the state. Between 1946 and 1950, the Polk County increase was 11.5 percentage points, comfortably above the statewide increase of 8.2. Between 1948 and 1952, Polk County again recorded an increase in voter turnout above the statewide figure, 18.2 compared with 13.4 percentage points. ${ }^{17}$ The failure of Democrats in Polk County to surpass those in other parts of the state in registering Democratic percentage-of-the-vote increases during the BeardsleyLoveless years, however, suggests that not nearly all of the above-average increase in the county's turnout rate can be attributed to Democratic party organizational work.

Among the more transient factors cited as explanations of the early years of the Iowa Democratic revival are specific political issues and personalities. Interpretations of this type are most commonly offered in explaining the results of particular elections, e.g., the narrow Republican gubernatorial victory in 1952 , or the election of a Democratic governor four years later. In the first six years of the 1950s, the substantive issues included proposals to permit the union shop, others to reapportion the legislature, and some to legalize the sale of liquor by the drink. The sales tax, particularly after the legislature increased it from 2 to $2 \frac{1}{2}$ percent in 1955 , also attracted much attention. ${ }^{18}$

${ }^{17}$ U.S. Department of Commerce, Bureau of the Census, Sixteenth Census of the United States: 1940, Population, Volume 2, Characteristics of the Population, Part 2, Florida-Iowa, pp. 872-877; U.S. Census of Population: 1950, Volume 2, Characteristics of the Population, Part 15, Iowa, pp. 83-99; U.S. Census of Population: 1960, Volume 1, Characteristics of the Population, Part 17, Iowa, pp. 110-134.

${ }^{18}$ Numerous issues of the Des Moines Register, and of the Sunday Register, 


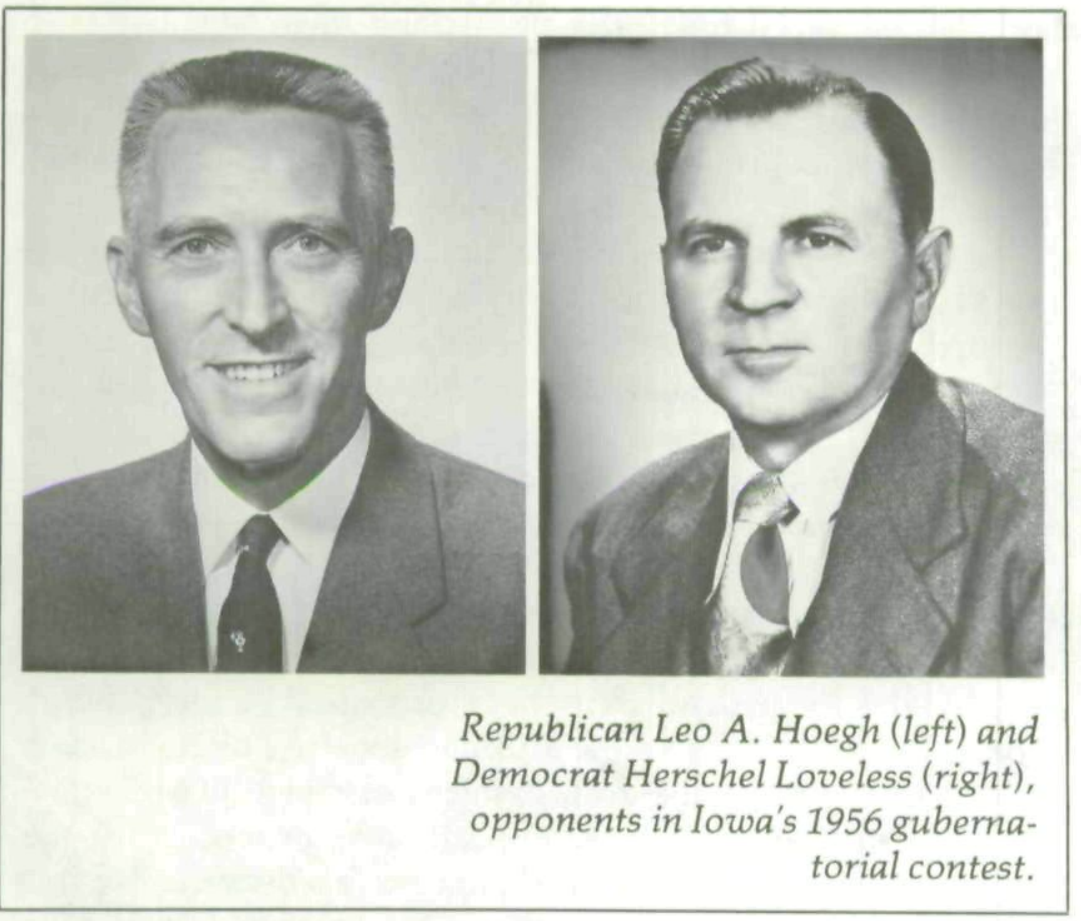

Although neither party in the 1950 s produced so dominant a political personality as Harold Hughes or Robert Ray, earlier writers emphasize personal as well as substantive factors in attempting to explain political developments during the Beardsley-Loveless years, with the personal and the substantive often combining to shape public perceptions of political figures. Among the factors cited were Governor Beardsley's decision to seek a third term in 1952 , thereby creating tensions within the Republican party. The third-term decision was especially interesting in view of Beardsley's successful challenge to an earlier Republican governor, Robert D. Blue in 1948, when that official sought the party's nomination for a third term. In addition to

indicate the more salient political questions of 1950-1956. Among others see: 10 October 1950, p. 7; 19 October 1950, p. 25; 2 November 1950, p. 18; 4 November 1950 , p. 3; 17 May 1954, p. 1-L; 24 May 1954, p. 3; 26 May 1954, p. 1; 29 May 1954, p. 1; 1 June 1954, p. 10; 3 June 1954, p. 1; 17 October 1954, p. 7-L; 20 May 1956, pp. 5-L, 6-L; 27 May 1954, p. 6-L; 8 November 1956, p. 1. 
those Republicans who criticized Beardsley when he announced for a third term, others, including his opponents in the 1952 Republican primary, faulted him for his well publicized personal income-tax problems, and for allegedly attempting to sell diseased livestock. ${ }^{19}$

Considerable numbers of Republicans also attacked Beardsley's successor, Leo A. Hoegh, whom Beardsley had appointed as attorney general, and who was widely regarded as Beardsley's choice in the six-candidate contest for the 1954 Republican gubernatorial nomination. Hoegh's convictions and actions combined to irritate many Republicans. These included conservative Republicans in general, and the members of the Iowa Manufacturers' Association in particular, both of whom resented Hoegh's support for legislation which would permit the union shop in Iowa, and his efforts to establish closer contacts between the Republican party and organized labor. ${ }^{20}$ Some criticized Hoegh for using the attorney general's office to curb the sale of liquor by the drink, which was then illegal, while others resented his announced opposition to proposals for the legalization of liquor by the drink, and for his definition of this as a moral issue. Hoegh's aggressive governorship, in which he resorted to publicizing the voting records of Republican legislators whom he accused of failing to support the party platform, is also alleged to have alienated many Republicans. ${ }^{21}$

His record regarding taxation is widely believed to have contributed to Hoegh's defeat in his 1956 bid for re-election. Perhaps the most publicized action was the governor's acceptance of a 1955 bill increasing the sales tax from 2 percent to $2 \frac{1}{2} 2$ percent, even though he opposed the measure, and in 1956 campaigned for a return to the lower rate. According to Hoegh's supporters, his creation of an Iowa Tax Study Commission, which he hoped would contribute to efforts to make the state's tax system more fair, instead persuaded many that he sought to

${ }^{19}$ Register: 22 May 1952, p. 1; 25 May 1952, p. 2-L; 28 May 1952, p. 1; 29 May 1952, p. 1; 1 June 1952, p. 2-L; 2 November 1952, p. 3-L; 5 November 1952, p. 11.

${ }^{20}$ Register: 1 October 1954, p. $1 ; 14$ October 1954, p. 1;18 October 1954, p. 1; 1 November 1956, p. 9.

${ }^{21}$ Sunday Register, 21 October 1956, p. 20-G. 
increase taxes. By 1956, Herschel Loveless and the Democratic party fastened on Hoegh's record in the field of taxation, as they campaigned against "High Tax Hoegh." Also alleged to have weakened the governor for his bid for re-election were his many travels, in Iowa and outside the state, as well as his butch haircut and his small mustache. ${ }^{22}$ By their very nature it is difficult, if not impossible, to evaluate many of these explanations of Democratic gains and Republican losses in contests for the governorship in the elections of 1952,1954, and 1956. At least one of the explanations, however, can be tested by the use of aggregate voting data.

Although Republican and Democratic candidates for governor during these years differed consistently and clearly in their announced positions on the question of the legalization of the sale of liquor by the drink, and large numbers of Iowans on each side of the issue appeared to regard it as a matter of considerable importance, its impact upon voting behavior appears to have been negligible, as Table 3 indicates. Although counties where dry sentiments were strongest increased their Democratic gubernatorial vote slightly less than other counties between 1950 and 1952, they recorded slightly larger Democratic increases than other counties four years later, as well as for the entire six-year period beginning with the election of 1950. The size of all of the correlations suggests that, despite the considerable amount of interest in the issue, it was not sufficient to modify traditional voting habits. There is no evidence that the increased support among Iowans for the legalization of liquor by the drink, as reported by the Des Moines Register's Iowa Poll, explains their increased approval of Democratic gubernatorial candidates during these years. ${ }^{23}$

Although urban counties registered larger Democratic gubernatorial percentage increases than rural counties from 1950 to 1952, the latter posted the largest Democratic gains between 1954 and 1956, thereby enabling the traditional minority party to capture the governorship for the first time in twenty years.

${ }^{22}$ Register: 18 October 1956, p. 3; 23 October 1956, p. 4; 1 November 1956, p. 9; 8 November 1956 , pp. 9, 10.

${ }^{23}$ Sunday Register: 15 June 1952, p. 4-A; 28 March 1954, p. 7-L; 24 February 1957, p. 12-G. 
Discontent with Hoegh contributed significantly to the voting behavior of Iowa Republicans who abandoned the incumbent in his bid for a second term. Another factor, however, was crucial in the creation of a Democratic gubernatorial majority in 1956. This was the growing discontent of Iowa farmers with the level of farm prices and with the agricultural policies of the Eisenhower administration. Although all but two Iowa counties gave Adlai Stevenson a larger percentage of their vote in 1956 than in 1952, rural counties posted the largest Democratic percentage increases, as Table 3 indicates. Two of the most urban counties in the state, Dubuque and Linn, recorded the only decreases in the Democratic percentage of the presidential vote between 1952 and 1956. This statewide reduction in the Republican vote at the head of the ticket, combined with the high rate of ticket splitting, enabled Iowa Democrats to capture the governorship which had eluded them during most of the state's history.

Most observers contend that a large turnout benefits Democratic candidates; however the record of the Beardsley-Loveless years offers little support for that conclusion. Despite the coincidence of the increase in the Democratic gubernatorial vote with the increase in the total vote in 1952, analysis of the two developments indicates that, at least in Iowa, Eisenhower was the chief beneficiary of the large increase in turnout. ${ }^{24}$ While it is difficult to estimate the proportion of new voters who cast ballots for Loveless, it appears clear that the largest contributions to his close race in 1952, as well as to his election four years later, were the continued high level of support by Democrats and a substantial increase in the Democratic gubernatorial vote among Republicans.

Although the relatively larger voter turnout of the last thirty years may have contributed to some of the Democratic gains of this period, its impact on the Democratic gubernatorial

${ }^{24} \mathrm{~A}$ further indication that a large vote did not necessarily benefit Democratic candidates is available in the 1950 gubernatorial election. In that contest, 39.7 percent more lowans voted for governor than in the preceding off-year election. Despite the sharp increase in voter turnout, the Democratic share of the vote for governor decreased from 42.1 percent in 1946 to only 40.5 percent in 1950 . 
advances of 1950 through 1956 was slight. The most important new ingredient in the elections of 1952, 1954, and 1956 was the troubles of the Beardsley and Hoegh administrations. In the election of 1956, agrarian discontent with the farm policies of the Eisenhower administration weakened the Iowa Republican party further, enabling Loveless to capture the governorship the Democrats had missed so narrowly in the two preceding elections. Somewhat like Franklin D. Roosevelt's presidential victory in 1932, Herschel Loveless won the Iowa governorship in 1956 primarily because he was the Democratic candidate at a time when the Republican incumbent no longer received the support of all persons who had voted Republican regularly in the past.

\section{The Iowa Democratic revival of the third quarter of the} twentieth century started on a small scale in the early 1950s, with narrow Democratic defeats in the 1952 and 1954 gubernatorial contests, followed by an equally-slim Democratic victory in the 1956 gubernatorial election. As subsequent events would demonstrate, these were the early developments in a statewide political upheaval which continued to unfold in the 1960 s and 1970s, first in gubernatorial, later in congressional and other elections.

Although increases in the Democratic share of the vote for other offices soon followed the party's gubernatorial gains, the earlier advances occurred independently of any general move toward the Democratic party by Iowa voters in the early 1950s. Indeed, the 7.3 percentage point increase in the Democratic share of the gubernatorial vote between 1950 and 1952 occurred despite a sharp increase ( 16.2 percentage points) registered in the Republican presidential vote between 1948 and 1952, and the impressive Republican gains in contests for other state offices from 1950 to 1952. Although widespread decreases in the Republican share of the presidential vote between the first and the second Eisenhower elections, and the 1952 to 1954 and 1954 to 1956 Republican decreases in other statewide contests, can be interpreted as evidence of a Democratic realignment, the decreases of 1952 to 1954 and of 1952 to 1956 were from the unusually high Republican percentages of 1952. Despite these de- 
creases, the 1956 Republican percentages for president and for such state offices as auditor were equal to, or above, the comparable vote in recent presidential years before 1952. As the data in Table 1 indicate, Democratic gubernatorial gains in the early 1950 s occurred without parallel changes in the distribution of the vote for other statewide offices. The failure of other Democratic candidates to approximate the 1952 to 1956 achievements of the party's gubernatorial nominees suggests that neither urbanization-industrialization nor Democratic party revitalization contributed significantly to the party's increasing share of the vote for governor. Had either of these other factors been primary elements in the increased Democratic gubernatorial vote of 1950 to 1956, their role should have been evident in an across-the-ticket increase in the party's share of the Iowa vote.

It was divisions within the Iowa Republican party, rather than urbanization-industrialization or Democratic party revitalization, which permitted Herschel Loveless and Clyde Herring, in 1952 and 1954, to run much closer to their Republican opponents than previous Democratic gubernatorial candidates since 1938 had done. With the aid of lower farm prices and of a smaller voter turnout, both of which contributed to a decreased Republican share of the vote at all levels, Loveless then defeated Leo Hoegh in 1956, as each made a second bid for the state's highest office. The continuing gap between the Democratic gubernatorial vote and the party's vote for other state offices, e.g., auditor, treasurer, secretary of agriculture, and attorney general, suggests strongly that Democratic gubernatorial gains were well above any more general Democratic increase in the 1950s.

Democratic gubernatorial advances of the 1950s could have resulted from either, or both, of two sources. One was Democratic strength; the other was Republican weakness. Although both Loveless and Herring ran far ahead of other Democratic gubernatorial candidates of the 1940s and 1950s, neither appears to have been a strong or popular candidate of the Dwight Eisenhower, the Harold Hughes, or the Robert Ray variety. After winning re-election in 1958, Loveless lost a 1960 bid for the United States Senate to Republican Jack Miller, who had earlier won only 30.8 percent in the six-candidate Republi- 
can primary. Herring's moment of glory was even briefer, as his 1954 gubernatorial near-miss was his only statewide candidacy.

Republican weakness is the best explanation of Democratic gubernatorial gains in the 1950s. Beardsley's income tax and other troubles created serious divisions within the Republican party in 1952, resulting in a bitter primary battle and in widespread Republican defection in the general election. As Beardsley's chosen successor, Hoegh inherited his predecessor's problems, and added to them with his liberal views and his style of political operation. Had Beardsley retired voluntarily after two terms, or had he lost his 1952 primary bid, it is probable that the party's gubernatorial nominee would have ridden the Eisenhower coattails, as well as the sizeable Republican majority among Iowa voters, to an easy victory in 1952 . Without the Republican near-defeat that year, and the divisiveness resulting from it, it is highly unlikely that Iowa Democrats would have posed much of a threat to continued Republican domination of the governor's office in subsequent 1950s or early 1960s elections. Eisenhower's continued popularity in the state in 1956, as well as Nixon's in 1960, suggests that Iowa Democrats would not have captured the governorship any earlier than the 1964 Barry Goldwater debacle. Had Iowa entered that election with a Republican governor, it is highly improbable that the party's problems at the presidential level would have produced Democratic gains of the magnitude recorded in 1964. Without Harold Hughes as a popular incumbent in 1964 , it is inconceivable that Iowa Democrats could have recorded the sweeping victories they achieved when they had both Hughes and Goldwater to aid them in registering a Democratic landslide that year.

Gubernatorial factionalism within the state's Republican party contributed more than any other factor to the electoral accomplishments-both victories and near-victories-of the gubernatorial wing of the Iowa Democratic party, 1952 to 1966. The election and the subsequent administrations of Democratic governors Loveless and Hughes then persuaded significant numbers of Iowa voters to cast their ballots for Democratic candidates for other offices, thereby contributing to an increased Democratic vote at all levels in the longtime Republican stronghold. 
Copyright of Annals of Iowa is the property of State of Iowa, by \& through the State Historical Society of Iowa and its content may not be copied or emailed to multiple sites or posted to a listserv without the copyright holder's express written permission. However, users may print, download, or email articles for individual use. 